\title{
STRATEGI PEMASARAN YANG EFEKTIF DALAM MENINGKATKAN MINAT MENABUNG NASABAH DI ERA COVID-19
}

\author{
Nur Hasanah Dewi \\ Fakultas Ekonomi Bisnis UIN Raden Intan Lampung \\ Muhammad Iqbal Fasa* \\ Fakultas Ekonomi Bisnis UIN Raden Intan Lampung \\ Suharto \\ Fakultas Ekonomi Bisnis UIN Raden Intan Lampung \\ Lita Monalysa \\ STEBI Lampung
}

\begin{abstract}
Savings are a basic necessity for the community, with savings can be a provision in the future, with savings can make life more efficient, with savings that can prosper the people, many things are one of the functions of the bank institution. So that at least we can practice saving from the earliest possible age, this is a factor that can be the basis for the author to take the topic of saving. The awareness of saving is now starting to be grown in children with the hope that it can become a learning medium for children to live frugally in the midst of this increasingly modern era. In addition, this program also aims to raise more funds from third parties or the public in the context of company expansion, as evidenced by the presence of several banking companies that have launched consumer banking products in the form of savings for children.
\end{abstract}

Keywords: Marketing strategy, interest in saving, banking

Paper type: Research paper

*Corresponding author: miqbalfasa@ radenintan.ac.id

Received: April 25, 2021; Accepted: November 13, 2021; Available online: December, 06, 2021

Cite this document:

Dewi, N. H., Fasa', M. I., Suharto, \& Monalysa, L. (2021). Strategi Pemasaran yang Efektif dalam Meningkatkan Minat Menabung Nasabah di Era Covid-19. Jurnal Masharif Al-Syariah: Jurnal Ekonomi dan Perbankan Syariah, 6(3), 777786. doi:http://dx.doi.org/10.30651/jms.v6i3.8062

Copyright (C) 2021, Jurnal Masharif Al-Syariah: Jurnal Ekonomi dan Perbankan Syariah http://journal.um-surabaya.ac.id/index.php/Mas/index

This article is licensed under a Creative Commons Attribution-NonCommercial 4.0 International License. 


\begin{abstract}
Abstrak
Tabungan merupakan kebutuhan pokok bagi masyarakat, dengan tabungan dapat menjadi bekal dimasa yang akan datang, dengan tabungan dapat membuat hidup lebih hemat, dengan tabungan yang dapat mensejahterakan masyarakat, banyak hal yang merupakan salah satu fungsi dari lembaga bank. Sehingga setidaknya kita bisa berlatih menabung sejak usia dini, hal ini menjadi faktor yang bisa menjadi dasar bagi penulis untuk mengambil topik menabung. Kesadaran menabung kini mulai ditumbuhkan pada anak-anak dengan harapan dapat menjadi media pembelajaran bagi anak-anak untuk hidup hemat di tengah era yang semakin modern ini. Selain itu, program ini juga bertujuan untuk menghimpun lebih banyak dana dari pihak ketiga atau masyarakat dalam rangka ekspansi perusahaan, terbukti dengan hadirnya beberapa perusahaan perbankan yang telah meluncurkan produk consumer banking berupa tabungan untuk anak.
\end{abstract}

Kata kunci: Strategi pemasaran, minat menabung, perbankan

\title{
PENDAHULUAN
}

Pertumbuhan ekonomi suatu negara membutuhkan pola pengaturan sumber-sumber daya yang tersedia secara terarah dan terpadu, sehingga hasil yang optimal bisa didapat dan digunakan untuk peningkatan kesejahteraan masyarakat. Lembaga-lembaga ekonomi harus melaksanakan pola tersebut secara bersamaan agar tujuan pembangunan ekonomi yang diharapkan dapat tercapai dan sesuai dengan rencana pembangunan nasional. Lembaga kauangan, khususnya perbankan mempunyai peran yang strategis dalam menggerakkan roda perekonomian suatu negara. Bank mempunyai fungsi dan peranan penting dalam perekonomian nasional di lihat dari kondisi masyarakat sekarang, jarang sekali orang yang tidak mengenal dan tidak berhubungan dengan Bank. Hampir semua orang berkaitan dengan lembaga keuangan. Pada mulanya kegiatan perbankan dimulai dari jasa 
penukaran uang, sehingga dalam sejarah perbankan arti bank di kenal sebagai meja tempat menukarkan uang, dimana kegiatan penukaran uang tersebut sekarang dikenal dengan pedagang valuta asing. Dalam perkembangan selanjutnya kegiatan perbankan lagi menjadi tempat penitipan uang, yang kini dikenal dengan kegiatan simpanan (tabungan). Kegiatan perbankan bertambah lagi sebagai tempat peminjaman uang. Dalam upaya menarik minat nasabah untuk menabung di bank dilakukan berbagai upaya. Salah satunya yaitu penetapan suku bunga bank. Tingkat suku bunga yang ditetapkan bank akan berdampak terhadap perilaku nasabah bank. Bunga yang diberikan oleh bank kepada nasabah merupakan daya tarik bagi masyarakat untuk melakukan penyimpanan uangnya di bank konvensional. Selain tingkat suku bunga yang ditetapkan bank, ada faktor lain yang harus diperhatikan oleh bank untuk dapat menarik minat nasabah yaitu upaya bank untuk memasarkan produknya yaitu promosi. Kegiatan promosi yang dilakukan bank menjadi sarana untuk memperkenalkan produk yang dimiliki bank kepada nasabah sehingga nasabah mengenal lebih jauh produk-produk yang ditawarkan bank. Selain tingkat suku bunga yang ditetapkan bank, ada faktor lain yang harus diperhatikan oleh bank untuk dapat menarik minat nasabah yaitu upaya bank untuk memasarkan produknya yaitu promosi. Kegiatan promosi yang dilakukan bank menjadi sarana untuk memperkenalkan produk yang dimiliki bank kepada nasabah sehingga nasabah mengenal lebih jauh produk-produk yang ditawarkan bank. Penentuan marketing mix (bauran pemasaran) merupakan kegiatan pemasaran yang dilakukan secara terpadu. Artinya kegiatan ini dilakukan secara bersamaan di antara elemen-elemen yang ada dalam marketing mix itu sendiri. Setiap elemen tidak dapat berjalan sendiri tanpa dukungan dari elemen lain. Penggunaan marketing mix dalam dunia perbankan dilakukan dengan menggunakan konsep-konsep yang sesuai dengan kebutuhan bank. Dalam praktiknya, konsep bauran pemasaran terdiri dari bauran pemasaran untuk produk yang berupa barang maupun jasa. Khususnya untuk produk yang 
berbentuk jasa diperlukan konsep sedikit berbeda dengan produk barang. Marketing mix untuk produk jasa memiliki konsep 7P (Price, Place, Promotion, Product, People, Process, Packaging). Kesadaran menabung kini mulai ditumbuhkan pada anak-anak. Dengan tujuan untuk menghimpun lebih banyak dana dari pihak ketiga atau masyarakat dalam rangka ekspansi perusahaan terbukti dengan adanya beberapa perusahaan perbankan yang meluncurkan produk consumer banking berupa tabungan untuk anak-anak yang rata-rata umur 0-12 tahun, misalnya saja bank BNI dengan produknya Taplus Anak, BJB dengan produknya tandamata My First serta lain sebagainya .(Sirait \& Sinaga, 2020)

Tabungan BTN Junior merupakantabunganyang ditujukan untuk khusus segmen anak usia $<12$ tahun sebagai tabungan edukasi bagi anak untuk memulai belajar dan membudayakan menabung. Secara aktif perusahaan harus dapat meraih konsumen potensial untuk produk baru yang diluncurkan sehingga dapat memberikan keuntungan bagi perusahaan dan unggul dalam strategi pemasaran untuk memasarkan produk. Dampak dari perubahan teknologi juga berdampak postif terhadap perkembangan dunia perbankan. Produk yang ditawarkan nasabahnya menjadi lebih cepat dan efisien.(2.Pdf, n.d.)

\section{LANDASAN TEORI}

\section{Pengertian Bank}

Sistem perbankan di Indonesia dibedakan berdasarkan fungsinya yang terdiri dari Bank Sentral, Bank Umum dan Bank Perkreditan Rakyat (BPR) Pengertian bank menurut Undang-undang Negara Indonesia Nomor 10 Tahun 1998 Tanggal 10 November 1998 tentang perbankan yang dimaksud dengan Bank adalah badan usaha yang menghimpun dana dari masyarakat dalam bentuk simpanan dan menyalurkannya kepada masyarakat dalam bentuk kredit dan atau bentuk-bentuk lainya dalam rangka meningkatkan taraf hidup rakyat banyak. Menurut Undangundang No. 13 tahun 2004 menggantikan Undang-undang No. 13 tahun 
1968 tentang Bank Sentral "merupakan lembaga negara yang independen, bebas dari campur tangan pemerintah dan atau pihak-pihak lainya. Sebagai bank sentral, bank Indonesia ditunjuk sebagai lembaga yang berwenang mengeluarkan dan mengatur peredaran uang rupiah sebagai alat pembayaran yang sah". Disamping itu, Bank Indonesia diberikan tugas untuk mengatur da menjaga kelancaran sistem pembayaran.(Andespa, 2017)

Beberapa sektor usaha terdampak oleh wabah pandemi virus korona (Covid-19), termasuk di dalamnya adalah sektor perbankan. Oleh karena itu, agar sektor perbankan dapat tetap eksis di tengah pandemi virus korona, maka perbankan harus melakukan mitigasi risiko secara cermat, serta menggunakan strategi kreatif menghadapi kondisi yang serba tidak menentu saat ini.

Wabah pandemi Covid-19 memaksa individu /kelompok/ institusi/negara, untuk mengubah pola hidup dan prilakunya selama ini. Jika individu/kelompok/institusi/negara, tidak melakukan perubahan, maka dengan sendirinya perubahan tersebut yang akan melindasnya, tanpa terkecuali di dalamnya sektor usaha perbankan. Jika bank ingin keluar dari kondisi keterpurukan, maka sepatutnya bank tidak dapat menggunakan metode atau cara-cara lama dalam memasarkan layanan produk dan jasanya. Korona telah mendekonstruksi tatanan/sistem perbankan yang sudah berjalan selama ini.(Indi, 2019)

Adapun strategi bank yang dapat dilakukan di tengah pandemi, yaitu melalui:

1. Bank harus mengelola mitigasi risiko dengan tepat. Bank harus punya peta navigasi baru untuk dapat menghadapi krisis yang ada. Proses mapping debitur untuk proses restrukrisasi harus segera jalan dan jelas sehingga cashflow bank terlihat setelah melakukan treatment. Dengan begitu, bank mengetahui posisi Strengths-Weakness-Opportunities-Threats (SWOT) untuk 
dapat membuat revisi Rencana Bisnis Bank (RBB) dengan memperhatikan kondisi karena Korona.

2. Bank harus fokus pada industri yang prospek untuk dibiayai. Bank harus tebang pilih pada sektor usaha yang eksis dan berkembang di tengah merebaknya wabah Korona. Adapun, menurut riset Dcode EFC (2020), sektor usaha (potential winner) tersebut adalah sektor; agribisnis, telekomunikasi, ritel e-commerce, farmasi, produk pembersih \& alat kesehatan.

Dan, untuk sektor-sektor yang terkapar merugi ataupun sektorsektor yang hingga tidak mempunyai prospek sama sekali untuk bangkit, maka, sebaiknya tidak menjadi pilihan bank atas pembiayaan kreditnya terlebih dahulu. Harapannya, bank tidak lagi bekerja dengan membawa beban kredit macet atas ekspansi kredit barunya.

3. Digital banking. Layanan produk dan jasa harus dikonversi menjadi digital banking. Proses tersebut harus berjalan bertahap dan inisiasinya dilakukan secara terus menerus. Namun, tidak semua produk dan jasa harus menggunakan digital banking, terdapat bisnis inti yang masih membutuhkan fungsi oleh unsur manusia. Beberapa fungsi yang melibatkan unsur manusia, sehingga keberadaannya tidak dapat digantikan oleh digital banking. Salah satu peran tersebut adalah aktivitas pendampingan dan konsultasi bisnis. Sebagai contoh, misalnya ketika nasabah bank yang bisnisnya terganggu akibat Covid-19, maka ia akan mendapatkan pendampingan dan konsultasi bisnis dari tenaga pemasar bank. Bank memiliki Relationship Manager (RM) yang tersebar di seluruh Indonesia. Peran RM ini akan mendampingi sekaligus sebagai konsultan apabila nasabah mengalami masalah dalam operasional bisnisnya.

4. Inovasi dan kreativitas bank. Korona menuntut bank harus semakin berinovasi. Misalkan, bank saat ini tidak hanya menuntut 
pembayaran angsuran dan bunga kredit oleh debiturnya. Namun, bank juga harus memikirkan untuk dapat membantu nasabah, melalui penjualan produknya. Seperti diketahui, imbauan pemerintah agar masyarakat melakukan physical distancing maupun social distancing mempengaruhi penjualan pelaku Usaha Mikro Kecil Menengah (UMKM). Menyiasati hal tersebut, bank dapat membantu pelaku UMKM binaannya untuk terhubung dengan ekosistem sehingga mampu berjualan secara online. Contohnya adalah dengan create UMKM Go Online. UMKM Go Online merupakan platform digital yang bertujuan untuk memfasilitasi UMKM binaan Bank dalam memperluas jangkauan penjualan produk mereka. Para pelaku UMKM yang berminat masuk dalam UMKM Go Online cukup melalui proses tahapantahapan mudah. Nasabah wajib melengkapi data dan mendaftarkan usahanya terlebih dahulu dengan mengakses microsite UMKM Go Online di website bank lewat tautan portal bank. Selanjutnya, pihak penjual akan diminta untuk menyiapkan dokumentasi produk, mengirimkan sampel barang, hingga proses pengiriman barang ke gudang-gudang inventori yang dikelola oleh bank. Barang tersebut selanjutnya akan dibantu oleh bank untuk dijual melalui platform UMKM Go Online. Produkproduk unggulan dari UMKM mitra binaan bank dapat langsung dibeli di e-commerce rekanan seperti Qoo10 Singapura, Tokopedia, Shopee, Bukalapak, Blanja.com dan Blibli.com.

5. Pergunakan tools zoom untuk On The Spot (OTS). Ketika pemerintah mengharuskan social distancing ataupun physical distancing, maka, harapannya respon bank ialah dengan memberlakukan verifikasi jaminan kredit di lapangan atau OTS melalui video call atau zoom.

6. pendampingan dan konsultasi bisnis. Nasabah UMKM yang bisnisnya terganggu akibat Covid-19 mendapatkan pendampingan 
dan konsultasi bisnis oleh staf bank, yaitu relationship manager (RM) yang tersebar di seluruh Indonesia. Peran RM ini, akan melakukan pendampingan sekaligus sebagai konsultan apabila pinjaman nasabah dilakukan restrukturisasi hingga proses restrukturisasi tersebut berjalan lancar.

7. program Tanggung Jawab Sosial Perusahaan atau Corporate Social Responbility (CSR) melalui pendidikan dan pelatihan online bagi pelaku UMKM. Bank dapat menyelenggarakan program pendidikan dan pelatihan online 'Bank Virtual Training and Education' yang dilakukan melalui aplikasi UMKM Go Online. Ini merupakan upaya Bank untuk terus mendorong para pelaku UMKM untuk meningkatkan kapasitas diri dan usahanya di tengah imbauan pemerintah untuk pembatasan fisik yang berguna untuk menekan penyebaran Covid-19.(Putri, 2020)

\section{HASIL DAN PEMBAHASAN}

Secara keseluruhan ada 4 strategi pemasaran yang diterapkan oleh Bank yaitu: Pamasaran yang dilakukan oleh Front Liner (CS, Teller, Security) dengan target pasar yaitu orang yang datang langsung ke Bank. Front Liner tersebut akan Cross Selling atau menawarkan kepada nasabah produk yang sesuai dengan profil nasabah dan bisa menambah portofolio, Pemasaran yang dilakukan oleh pihak Funding dengan target pasar yaitu nasabah potensial yang baru dan belum terjangkau oleh Front Liner. Pihak funding biasanya akan menawarkan produk nya lewat telepon dan bisa juga lewat referensi, Pemasaran yang dilakukan oleh Outletoutlet (Kantor Kas dan KCP) yaitu sama seperti yang dilakukan oleh Front Liner dan mereka juga menawarkan produknya lewat telepon, Pemasaran yang dilakukan oleh pihak Manajemen dengan target pasar nasabahnasabah besar yang mempunyai simpanan 100 Milyar keatas dengan cara mendatangi secara langsung ke tempat nasabah tersebut. (Khoirani, 2020)

Cara Bank mengatasi masalah diatas yaitu sebagai berikut: 
1. Mentolelir selama tidak terlalu banyak jumlahnya dan masih bisa diberi fee kolektif selama masih masuk akal karena masih bekerja sama dengan sekolah tersebut.

2. Untuk mengatasi data yang tidak lengkap pihak akan bekerja sama dengan wali kelas untuk membantu mengkoordinir siswanya yang belum melangkapi data, lalu pegawai BTN akan melakukan kunjungan rutin setiap minggu untuk menerima kelengkapan data dan menerima bila ada setoran yang masuk(Aziz \& Hendrastyo, 2020).

\section{KESIMPULAN}

Tabungan menjadi kebutuhan pokok bagi masyarakat, dengan tabungan dapat menjadi bekal dikemudian hari, dengan tabungan dapat menjadikan hidup lebih hemat, dengan tabungan dapat mensejahterakan rakyat banyak hal tersebut merupakan salah satu fungsi dari lembaga bank. Sehingga setidaknya dapat melatih menabung dari usia sedini mungkin, hal tersebut merupakan faktor yang dapat mendasar penulis untuk mengambil topik mengenai tabungan. Kesadaran menabung kini mulai ditumbuhkan pada anak-anak dengan harapan dapat menjadi media pembelajaran anak akan hidup hemat di tengah perkembangan jaman yang semakin modern ini. Selain itu program ini juga bertujuan untuk menghimpun lebih banyak dana dari pihak ketiga atau masyarakat dalam rangka ekspansi perusahaan terbukti dengan adanya beberapa perusahaan perbankan yang meluncurkan produk consumer banking berupa tabungan untuk anak-anak.

\section{DAFTAR PUSTAKA}

2.pdf. (n.d.).

Andespa, R. (2017). Faktor-Faktor yang Mempengaruhi Minat Nasabah

Dalam Menabung di Bank Syariah. Al Masraf: Jurnal Lembaga Keuangan Dan Perbankan, 2(1), 43-57.

Aziz, N., \& Hendrastyo, V. S. (2020). Pengaruh Kualitas Layanan, 
Kepercayaan Dan Promosi Terhadap Minat Nasabah Menabung Pada Bank Syariah Cabang Ulak Karang Kota Padang. Jurnal Pundi, 3(3), 227. https://doi.org/10.31575/jp.v3i3.183

Indi, I. (2019). Faktor-Faktor Yang Memengaruhi Minat Masyarakat Menabung Di Bank Syariah (Studi Kasus Pada Masyarakat Di Kecamatan Rappocini Kota Makassar). Journal of Chemical Information and Modeling, 53(9), 1-21.

Khoirani, K. (2020). Analisis Faktor-Faktor Yang Mempengaruhi Minat Nasabah Terhadap Produk Tabungan Pendidikan Berasuransi Pada Bank Syariah Mandiri Cabang Kota Bogor. Nisbah: Jurnal Perbankan Syariah, 6(1), 42. https://doi.org/10.30997/jn.v6i1.1867

Putri, R. N. (2020). Indonesia dalam Menghadapi Pandemi Covid-19. Jurnal IImiah Universitas Batanghari Jambi, 20(2), 705. https://doi.org/10.33087/jiubj.v20i2.1010

Sirait, S., \& Sinaga, K. (2020). Analisis Strategi Pemasaran Terhadap Minat Nasabah Pada Perbankan Di Pematangsiantar. Jurnal Ekonomi Dan Bisnis (EK\&BI), 3(1), 248. https://doi.org/10.37600/ekbi.v3i1.126 